\title{
Contributions to the Knowledge of Leaf Beetle (Coleoptera: Chrysomelidae) Fauna in Elazığ, Erzincan and Tunceli Provinces, Turkey
}

\author{
Ebru Gül ASLAN (iD) 1*, Özgür Durmuş KAYA ${ }^{(D 2}$, Ebru ÜNAL (iD)1 \\ ${ }^{1}$ Süleyman Demirel University, Faculty of Arts and Science, Isparta, Turkey \\ 2Directorate of Forest Management, Tefenni-Burdur, Turkey \\ Geliş Tarihi (Received): 20.08.2020, Kabul Tarihi (Accepted): 04.10.2020 \\ $\square$ Sorumlu Yazar (Corresponding author*): ebruaslan@sdu.edu.tr \\ (C) +902462114053 且 +902462114399
}

\begin{abstract}
The study is based on leaf beetle material collected from Elazığ, Erzincan and Tunceli provinces of Turkey during 2018 and 2019. As a result of examined specimens 44 taxa are identified totally. The numbers of taxa according to the provinces are 23 from Elazığ, 15 from Erzincan and 11 from Tunceli. 19 out of 23 species in Elazığ, 12 out of 15 species in Erzincan and all the reported species in Tunceli are new records. Notes regarding some species are provided under the title "remarks". In addition, the presence of Galeruca spectabilis spectabilis (Faldermann, 1837) in Turkey is confirmed with the exact locality data. The present study aims to contribute Turkish leaf beetle fauna with new locality records.
\end{abstract}

Keywords: Biodiversity, Chrysomelidae, East Anatolia, fauna, leaf beetles

\section{Elazığ, Erzincan ve Tunceli İllerinin Yaprak Böceği (Coleoptera: Chrysomelidae) Fauna Bilgisine Katkılar}

ÖZ

Çalışma, 2018 ve 2019 yıllarında Elazığ, Erzincan ve Tunceli illerinden toplanmış yaprak böceği materyaline dayanmaktadır. İncelen örnekler sonucunda toplam 44 takson tespit edilmiştir. İllere göre tür sayıları Elazığ'dan 23, Erzincan'dan 15 ve Tunceli'den 11'dir. 23 türün 19'u Elazığ için ve 15 türden 12'si Erzincan için yeni kayıt niteliğindedir. Tunceli için rapor edilen türlerin tamamı bu il için yeni kayıttır. Bazı türlere ilişkin önemli notlar "açıklamalar" başlığı altında verilmiştir. Ayrıca, Galeruca spectabilis spectabilis'in (Faldermann, 1837) Türkiye'deki varlığı kesin lokalite verileriyle doğrulanmıştır. Bu çalışma Türkiye yaprak böceği faunasına yeni lokalite kayıtlarıyla katkı sağlamayı amaçlamaktadır.

Anahtar Kelimeler: Biyoçeşitlilik, Chrysomelidae, Doğu Anadolu, fauna, yaprak böcekleri

\section{INTRODUCTION}

Chrysomelidae, known also as leaf beetles, is one of the largest families of Coleoptera both in species richness and individual number. The group is represented by about 40.000 species throughout the world (there pro- bably exist 55.000 to 60.000 ) and more than 3.500 species in the Palaearctic region (Konstantinov et al., 2009; Jolivet, 2015). According to the latest data, Turkish Chrysomelidae fauna includes over 900 taxa arranged in 13 subfamilies, and about $10 \%$ of these are endemic to Turkey. (Ekiz et al., 2013; Özdikmen et al., 2014; Aslan and Başar, 2016).

Ebru Gül ASLAN, https://orcid.org/0000-0003-3073-186X Özgür Durmuş KAYA, https://orcid.org/0000-0002-9967-5264 Ebru ÜNAL, https://orcid.org/0000-0002-9197-4446 
Leaf beetles are involved in the phytophagous coleopterans together with Curculionidae and Cerambycidae, and are quite specific in terms of food preferences (Hsiao, 1994). Most of the Chrysomelidae species are mono or oligophagous. Their distribution is generally associated with the host plants' distributions. Chrysomelidae represents an important group not only because of their species richness but also their agricultural and economical importance.

Because of the limited number of studies there is still a great lack of information about actual leaf beetles of Eastern Anatolia Region of Turkey. The existing study provides a contribution for the current Chrysomelidae knowledge of this region by listing 44 species collected during field expeditions in Elazığ, Erzincan and Tunceli provinces.

\section{MATERIAL AND METHODS}

This study is based on material collected from several locations in Elazığ, Erzincan and Tunceli provinces of Turkey (Figure 1). Specimens were collected using sweep net and aspirator. The preparation of the samples and mounting on card boards as museum specimens was performed by standard methods. Finally, they were identified using some keys and papers (Čížek \& Doguet 2008, Warchałowski, 2010, Beenen, 2014). Specimens collected within this study are deposited at the Entomology Laboratory, Department of Biology of Süleyman Demirel University, Isparta, Turkey. Turkish distributions by province are given for each species with some notes when necessary. Distributions (when not stated) are based on Ekiz et al. (2013) and Özdikmen et al. (2014).

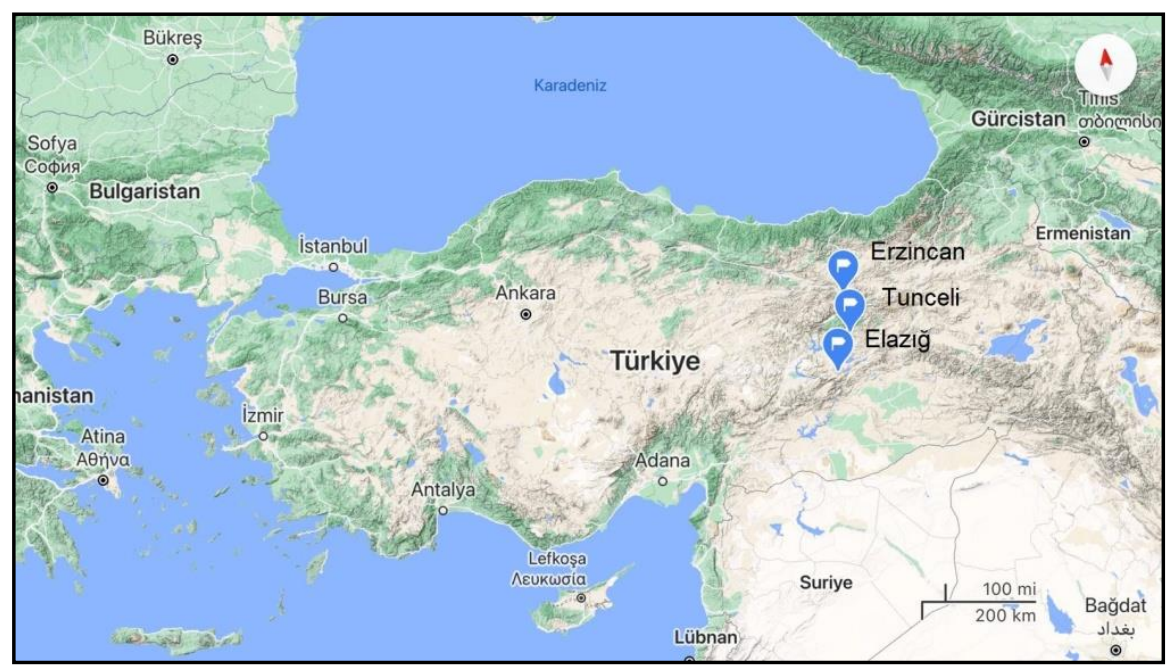

Figure 1. Map showing the provinces included in the study.

\section{RESULTS}

In total, 44 taxa (species and subspecies) within 23 genera are listed. The list of species is given below alphabetically.

Family Chrysomelidae Latreille, 1802

Subfamily Orsodacninae Thomson, 1858 Genus Orsodacne Latreille, 1802

1. O. variabilis Bally, 1877

Material examined: Elazığ: Kovancılar, İğdeli, 02.08.2018, 1 స.

Distribution in Turkey: Aydın, Isparta, İzmir. Recorded for the first time from Elazığ province.

\section{Subfamily Criocerinae Genus Lilioceris Reitter, 1913}

\section{L. merdigera (Linnaeus, 1758)}

Material examined: Erzincan: Çayırlı, 22.05.2019, $4 \hat{\sigma^{\top}}, 7$ 우우.

Distribution in Turkey: İzmir, Kahramanmaraş, Kütahya. Recorded for the first time from Erzincan province.

\section{Subfamily Clytrinae Genus Clytra Laicharting, 1781}

\section{C. novempunctata Olivier, 1808}

Material examined: Elazığ: Kovancılar, Yeşildere, 21.04.2018, 1 औ, 1 우. 
Distribution in Turkey: Adana, Afyon, Amasya, Ankara, Antalya, Artvin, Aydın, Bartın, Bolu, Bursa, Çankırı, Çorum, Denizli, Elazığ, Erzurum, Gaziantep, Giresun, Isparta, İzmir, Hatay, Kahramanmaraş, Karabük, Karaman, Kastamonu, Kayseri, Konya, Manisa, Mardin, Mersin, Muğla, Niğde, Osmaniye, Sakarya, Siirt, Sinop, Sivas, Tokat, Tunceli, Yozgat, Uşak (Bal et al., 2018a; Özdikmen et al. 2020a).

\section{C. weisei Monros, 1953}

Material examined: Elazığ: Palu, Büyükçaltı, 02.04.2018, 2 $\hat{\jmath}$; Kovancılar, Yeşildere, 19.04.2018, 2

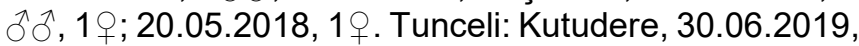
1 .

Distribution in Turkey: Ankara, Diyarbakır, Elazığ, Eskişehir, Gaziantep, Hakkari, Konya (Özdikmen et al., 2020b).

Remarks: The species was reported by Ekiz et al. (2013) from Asian Turkey. Later, Özdikmen et al. (2020b) confirmed the presence of this species in Turkey with exact locality data. The present study adds Tunceli for the first time to the distribution area of this species.

\section{Genus Coptocephala Chevrolat, 1836}

\section{C. unifasciata (Scopoli, 1763)}

Material examined: Elazığ: Kovancılar, İğdeli, 02.08.2018, 1 ऊ̂.

Distribution in Turkey: Adana, Afyon, Amasya, Ankara, Antalya, Aydın, Balıkesir, Bartın, Çanakkale, Çankırı, Erzincan, Erzurum, Hatay, Isparta, İzmir, Kahramanmaraş, Karabük, Kastamonu, Kayseri, Konya, Mersin, Muğla, Nevşehir, Niğde, Osmaniye, Sivas. Recorded for the first time from Elazığ province.

\section{Genus Labidostomis Germar, 1822}

\section{L. brevipennis Faldermann, 1837}

Material examined: Elazığ: Kovancılar, Yeşildere,

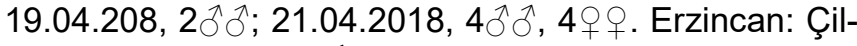
horoz, 29.06.2019, 1 \%, 1 ㅇ․

Distribution in Turkey: Bingöl, Çankırı, Hakkari, Konya, Malatya, Şırnak (Özdikmen et al., 2016). Recorded for the first time from both Elazığ and Erzincan provinces.

\section{L. cyanicornis (Germar, 1822)}

Material examined: Elazığ: Kovancılar, Yeşildere, 21.04.2018, 1ð, 1 \%.

Distribution in Turkey: Adana, Düzce, Konya. Recorded for the first time from Elazığ province.
Remarks: Recently reported also from Afyon (Gök and Bostan 2020).

\section{L. Iucida (Germar, 1824)}

Material examined: Elazığ: Kovancılar, Yeşildere,

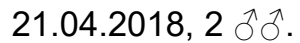

Distribution in Turkey: Antalya, Erzurum. Recorded for the first time from Elazığ province.

\section{L. maculipennis Lefèvre, $\mathbf{1 8 7 0}$}

Material examined: Elazığ: Merkez, 13.09.2018, $1 \delta^{\lambda}$. Distribution in Turkey: Amasya, Ankara, Antalya, Çankırı, Erzurum, İmir, Kayseri, Kırıkkale, Konya, Nevşehir, Niğde, Sivas, Van, Yozgat (Özdikmen et al., 2016). Recorded for the first time from Elazığ province.

\section{L. mesopotamica Heyden, 1886}

Material examined: Tunceli: Rabat, 30.06.2019, 1 ㅇ․ Distribution in Turkey: Aksaray, Ankara, Antalya, Bilecik, Bursa, Çankırı, Denizli, Erzincan, Erzurum, Eskişehir, Hatay, Isparta, İzmir, Kahramanmaraş, Kastamonu, Kayseri, Kocaeli, Konya, Kırşehir, Malatya, Mersin, Muğla, Muş, Nevşehir, Niğde, Sivas, Şanlıurfa, Yozgat (Özdikmen et al., 2016). Recorded for the first time from Tunceli province.

\section{Genus Smaragdina Chevrolat, 1836}

\section{S. scutellaris (Lefèvre, 1872)}

Material examined: Elazığ: Kovancılar, Yeşildere, 21.04.2018, 1万, 2 우우.

Distribution in Turkey: Ankara. Recorded for the first time from Elazığ province.

\section{S. vaulogeri (Pic, 1895)}

Material examined: Elazığ: Kovancılar, Yukarı Kazanlar, 17.05.2018, 1 ㅇ.

Distribution in Turkey: Gaziantep, Hatay, Isparta, Mersin, Osmaniye. Recorded for the first time from Elazığ province.

Remarks: Artvin (Gök and Turantepe, 2019) and Düzce (Özdikmen et al. 2020a) provinces are also recently added to the distribution area of this species.

\section{Genus Tituboea Lacordaire, 1848}

13. T. macropus (Illiger, 1800)

Material examined: Elazığ: Kovancılar, Yeşildere, 19.04.2018, 1 ㅅ, 2 우우. 
Distribution in Turkey: Adana, Aksaray, Ankara, Antalya, Artvin, Aydın, Bolu, Çanakkale, Çankırı, Çorum, Edirne, Erzurum, Hatay, Isparta, İstanbul, İzmir, Kahramanmaraş, Kastamonu, Karabük, Kars, Kayseri, Kilis, Konya, Mersin, Muğla, Nevşehir, Niğde, Osmaniye, Sivas. Recorded for the first time from Elazığ province.

Remarks: Diyarbakır also recently added to the distribution area of this species (Özdikmen et al. 2020a).

\section{Subfamily Cryptocephalinae Genus Cryptocephalus Geoffroy, 1762}

\section{C. elegantulus Gravenhorst, 1807}

Material examined: Erzincan: Çilhoroz, 29.06.2019, 1 .

Distribution in Turkey: Giresun, Konya, Niğde. Recorded for the first time from Erzincan province.

Remarks: Artvin also recently added to the known distribution area of this species (Gök and Turantepe, 2019).

\section{C. duplicatus Suffrian, 1847}

Material examined: Erzincan: Çilhoroz, 29.06.2019, $3 \hat{\jmath}$ ô, 1 ㅇ.

Distribution in Turkey: Adana, Amasya, Ankara, Antalya, Artvin, Bilecik, Bitlis, Bolu, Bursa, Çankırı, Çorum, Denizli, Erzincan, Erzurum, Eskişehir, Giresun, Gümüşhane, Hakkari, Isparta, İstanbul, İzmir, Kahramanmaraş, Karabük, Kars, Kastamonu, Kırklareli, Kocaeli, Konya, Kütahya, Manisa, Mersin, Nevşehir, Ordu, Sakarya, Samsun, Siirt, Sinop, Sivas, Tekirdağ, Tokat, Tunceli, Trabzon, Van, Yozgat, Zonguldak.

\section{C. anticus Suffrian, 1848}

Material examined: Erzincan: Çilhoroz, 29.06.2019, $1 \widehat{\widehat{T}}, 1$ 우.

Distribution in Turkey: Adana, Aksaray, Ankara, Antalya, Bayburt, Bilecik, Bolu, Bursa, Çanakkale, Çankırı, Denizli, Diyarbakır, Erzurum, Eskişehir, Gümüşhane, Hakkari, Isparta, İzmir, Karabük, Kocaeli, Kayseri, Kırıkkale, Konya, Manisa, Mardin, Mersin, Muş, Nevşehir, Niğde, Sakarya, Samsun, Sinop, Sivas, Tekirdağ, Tokat, Tunceli, Zonguldak. Recorded for the first time from Erzincan province.

\section{C. sericeus (Linnaeus, 1758)}

Material examined: Elazığ: Kovancılar, Yeşildere, 19.04.2018, 1 ऊ.

Distribution in Turkey: Ankara, Ardahan, Artvin, Balıkesir, Bursa, Çankırı, Çorum, Erzurum, Isparta, İzmir, Kastamonu, Kırklareli, Konya, Kars, Nevşehir,
Samsun. Recorded for the first time from Elazığ province.

Genus Pachybrachis Chevrolat, 1836

18. P. excisus (Weise, 1897)

Material examined: Tunceli: Rabat, 30.06.2019, $1 \hat{\jmath}$. Distribution in Turkey: Aksaray, Ankara, Antalya, Isparta, Niğde, Osmaniye. Recorded for the first time from Tunceli province.

19. P. tesselatus (Olivier, 1791)

Material examined: Elazığ: Kovancılar, Yeşildere, 21.04.2018, 1§, 1․ Erzincan: Çilhoroz, 29.06.2019, $1 \hat{0}, 1$ 우.

Distribution in Turkey: Adana, Afyon, Ağrı, Aksaray, Amasya, Ankara, Antalya, Bayburt, Bolu, Bursa, Çankırı, Çorum, Erzincan, Erzurum, Gaziantep, Gümüşhane, Isparta, İzmir, Kahramanmaraş, Karaman, Kars, Kayseri, Konya, Mardin, Mersin, Nevşehir, Niğde, Sivas, Tokat, Van. Recorded for the first time from Elazığ province.

\section{Subfamily Chrysomelinae Genus Chrysolina Motschulsky, 1860}

\section{C. hyperici (Forster, 1771)}

Material examined: Elazığ: Kovancılar, Yeşildere, 19.04.2018, 10, 1 \%.

Distribution in Turkey: Amasya, Ankara, Antalya, Bursa, Denizli, Erzurum, Isparta, İstanbul, İzmir, Kastamonu, Mersin, Samsun, Sinop. Recorded for the first time from Elazığ province.

\section{C. herbacea (Duftschmid, 1825)}

Material examined: Elazığ: Kovancılar, Yeşildere,

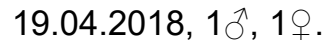

Distribution in Turkey: Afyon, Aksaray, Amasya, Ankara, Antalya, Artvin, Bartın, Bilecik, Bolu, Bursa, Burdur, Çankırı, Çorum, Denizli, Düzce, Edirne, Erzincan, Erzurum, Eskişehir, Gümüşhane, Isparta, İstanbul, Izmir, Kahramanmaraş, Karabük, Karaman, Kastamonu, Kayseri, Kırklareli, Kırşehir, Kocaeli, Konya, Manisa, Mersin Muş, Nevşehir, Niğde, Ordu, Osmaniye, Samsun, Sinop, Sivas, Tokat, Trabzon, Yozgat, Zonguldak (Özdikmen et al. 2020a). Recorded for the first time from Elazığ province.

22. C. orientalis (Olivier, 1807)

Material examined: Elazığ: Kovancılar, Yeşildere, 19.04.2018, $1 \delta^{\Uparrow}$. 
Distribution in Turkey: Adana, Afyon, Amasya, Ankara, Aydın, Bilecik, Bolu, Bursa, Diyarbakır, Elazığ, Erzurum, Eskişehir, Hatay, Isparta, İstanbul, İzmir, Kahramanmaraş, Karabük, Kastamonu, Kayseri, Kırşehir, Konya, Kütahya, Mersin, Nevşehir, Niğde, Ordu, Osmaniye, Samsun, Siirt, Sinop, Sivas, Tokat, Van, Yozgat, Zonguldak.

Remarks: Çankırı was also recently added to the known distribution area of this species (Bal et al., 2018a).

\section{Genus Entomoscelis Chevrolat, 1837}

\section{E. adonidis (Pallas, 1771)}

Material examined: Elazığ: Kovancılar, Yeşildere, 21.04.2018, 2 우우.

Distribution in Turkey: Afyon, Aksaray, Amasya, Ankara, Antalya, Ardahan, Burdur, Çankırı, Denizli, Diyarbakır, Düzce, Erzurum, Eskişehir, Gaziantep, Hatay, Isparta, İzmir, Karaman, Kahramanmaraş, Kastamonu, Kayseri, Kırıkkale, Konya, Karabük, Kırşehir, Nevşehir, Niğde, Sivas, Tokat, Yozgat, Zonguldak (Bal et al., 2018a; Özdikmen et al. 2020a). Recorded for the first time from Elazığ province.

\section{Subfamily Galerucinae Genus Agelastica Chevrolat, 1836}

\section{A. alni (Linnaeus, 1758)}

Material examined: Tunceli: Kutudere, 30.06.2019, $1 \widehat{ }$, $2 ㅇ$.

Distribution in Turkey: Adana, Antalya, Artvin, Balıkesir, Bursa, Erzurum, Eskişehir, Düzce, Giresun, Isparta, İstanbul, İzmir, Kahramanmaraş, Kırklareli, Kocaeli, Mersin, Osmaniye, Rize, Sakarya, Trabzon. Recorded for the first time from Tunceli province.

\section{Genus Calomicrus Dillwyn, 1829}

\section{C. lividus (Joannis, 1866)}

Material examined: Tunceli: Rabat, 30.06.2019, 3 우오. Distribution in Turkey: Adana, Ağrı, Antalya, Diyarbakır, Erzincan, Erzurum, Eskişehir, Hatay, Isparta, İzmir, Konya, Kars, Mersin, Osmaniye. Recorded for the first time from Tunceli province.

Remarks: Calomicrus trabzonus Lopatin \& Nesterova was proposed as new synonym of Calomicrus lividus by Bezdek (2018), thus Trabzon and Gümüşhane provinces were also added to the current distribution area of this species.

\section{Genus Exosoma Jacoby, 1903}

\section{E. thoracicum (Redtenbacher, 1843)}

Material examined: Elazığ: Kovancılar, Yeşildere, 21.04.2018, 10, 1 ㅇ.

Distribution in Turkey: Adana, Diyarbakır, Mardin, Şanlıurfa. Recorded for the first time from Elazığ province.

Remarks: Burdur was also recently added to the current distribution area of this species (Özdikmen et al. 2020a).

\section{Genus Galeruca Geoffroy, 1762}

\section{G. armeniaca Weise, 1866}

Material examined: Erzincan: Çilhoroz, 29.06.2019, $1 \hat{0}, 1$ ㅇ․

Distribution in Turkey: Afyon, Çankırı, Erzurum, Iğdır, Isparta, Kars (Bal et al., 2018a). Recorded for the first time from Erzincan province.

\section{G. jucunda Faldermann, 1837}

Material examined: Elazığ: Kovancılar, Çatakbaşı, 24.07.2018, 1ㅇ; Palu, Beydoğan, 16.11.2018, 1 ㅇ.

Distribution in Turkey: Ankara. Recorded for the first time from Elazığ province.

\section{G. spectabilis spectabilis (Faldermann, 1837)}

Material examined: Erzincan: Çilhoroz, 29.06.2019, 1ิㅅ․ 1 오.

Distribution in Turkey: In Ekiz et al. (2013), it was stated that $G$. spectabilis is only represented by the subspecies G. spectabilis orientalis in Turkey. But, Beenen (2010; 2019) listed Turkey in the general distribution area of this subspecies based on the previously identified Turkish specimens collected from Erzincan province (personal communication with R. Beenen, August 2020). However, this study represents the first certain locality record of the subspecies from Erzincan, and confirms its occurrence in Turkey.

\section{G. spectabilis orientalis Osculati, 1844}

Material examined: Elazığ: Kovancılar, Yeşildere, 21.04.2018, 3우; 21.06.2018, 10; Palu, Beydoğan, 16.11.2018, 1․ Erzincan: Çilhoroz, 29.06.2019, 1 ㅇ․ Distribution in Turkey: Aksaray, Ankara, Antalya, Ardahan, Artvin, Bayburt, Bolu, Çankırı, Erzurum, Kastamonu, Kayseri, Kırıkkale, Konya, Kars, Mersin, Nevşehir, Niğde, Sinop, Trabzon (Bal et al., 2018a; Özdikmen et al. 2020a). Recorded for the first time from both Elazığ and Erzincan provinces. 


\section{Genus Lochmaea Weise, 1883}

31. L. crataegi (Forster, 1771)

Material examined: Tunceli: Kutudere, 30.06.2019, 2 우.

Distribution in Turkey: Bolu, Erzurum, Eskişehir, Isparta. Recorded for the first time from Tunceli province.

\section{Genus Luperus Geoffroy, 1762}

\section{L. xanthopoda (Schrank, 1781)}

Material examined: Erzincan: Çilhoroz, 29.06.2019, 3 우.

Distribution in Turkey: Aksaray, Amasya, Ankara, Antalya, Çankırı, Erzurum, Eskişehir, Gümüşhane, Isparta, Konya, Kars, Niğde, Nevşehir. Recorded for the first time from Erzincan province.

Remarks: Recently reported also from Afyon by Gök and Bostan (2020), and Gaziantep by Özdikmen et al. (2020a).

\section{Genus Radymna Reitter, 1913}

\section{R. quadrimaculata (Redtenbacher, 1850)}

Material examined: Elazığ: Kovancılar, Yeşildere, 21.08.2018, $10^{\lambda}$.

Distribution in Turkey: Bingöl, Elazığ, Tunceli (Beenen, 2014).

Remarks: Beenen (2014) recorded this species for the first time from Turkey; this study represents the second record of the species.

\section{Genus Altica Müller, 1764}

\section{A. ancyrensis (Weise, 1897)}

Material examined: Erzincan: Çilhoroz, 29.06.2019,

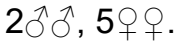

Distribution in Turkey: Ankara, Burdur, Erzurum, Konya, Nevşehir. Recorded for the first time from Erzincan province.

\section{A. lythri Aubé, 1843}

Material examined: Erzincan: Çilhoroz, 29.06.2019, 10, 1․ Tunceli: Rabat, 30.06.2019, 2 우.

Distribution in Turkey: Antalya, Denizli, Erzurum, Isparta, İmir, Mersin, Trabzon. Recorded for the first time from both Erzincan and Tunceli provinces.
36. A. oleracea (Linnaeus, 1758)

Material examined: Erzincan: Çilhoroz, 29.06.2019, $1 \hat{\text { 人र, }} 4$ 우오.

Distribution in Turkey: Ankara, Antalya, Burdur, Bayburt, Edirne, Erzurum, Eskişehir, Isparta, Kayseri, Konya, Kars, Nevşehir, Rize, Samsun, Sivas, Zonguldak.

Remarks: Recently recorded also from Afyon, Bolu, Düzce and Erzincan (Özdikmen et al. 2020a).

\section{Genus Longitarsus Latreille, 1829}

\section{L. aeneicollis (Faldermann, 1837)}

Material examined: Tunceli: Kutudere, 30.06.2019,

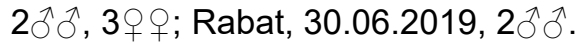

Distribution in Turkey: Adana, Ankara, Antalya, Çankırı, Erzincan, Erzurum, Iğdır, Isparta, Izmir, Kars, Mersin, Sivas (Bal et al., 2018b). Recorded for the first time from Tunceli province.

\section{L. luridus (Scopoli, 1763)}

Material examined: Tunceli: Rabat, 30.06.2019, $1 \hat{\jmath}$. Distribution in Turkey: Ankara, Antalya, Artvin, Burdur, Bayburt, Çankırı, Erzurum, Eskişehir, Isparta, İstanbul, Kırşehir, Sivas, Yozgat (Bal et al., 2018b). Recorded for the first time from Tunceli province.

\section{L. nanus (Foudras, 1860)}

Material examined: Tunceli: Kutudere, 30.06.2019, $3 \hat{\jmath} \hat{\jmath}, 5$ 웅 Rabat, $2 \hat{\jmath} \hat{\partial}, 1$ ㅇ․

Distribution in Turkey: Antalya, Erzurum, Isparta, Konya. Recorded for the first time from Tunceli province.

\section{L. nigrofasciatus (Goeze, 1777)}

Material examined: Erzincan: Çilhoroz, 29.06.2019, $1 \hat{0}, 1$.

Distribution in Turkey: Ankara, Antalya, Burdur, Bursa, Çankırı, Düzce, Edirne, Erzurum, Eskişehir, Isparta, Mersin (Bal et al., 2018b). Recorded for the first time from Erzincan province.

\section{Genus Neocrepidodera Heikertinger, 1911}

\section{N. ferruginea (Scopoli, 1763)}

Material examined: Erzincan: Çilhoroz, 29.06.2019, 2 우오.

Distribution in Turkey: Ankara, Antalya, Erzurum, Isparta, İstanbul, Kayseri, Konya, Sakarya. Recorded for the first time from Erzincan province. 
Remarks: Artvin and Afyon also added to the current distribution area of this species (Gök and Turantepe, 2019, Gök and Bostan 2020).

\section{Genus Psylliodes Latreille, 1825}

\section{P. inflata Reiche and Saulcy, 1858}

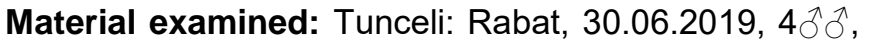
9 우오.

Distribution in Turkey: Adana, Antalya, Diyarbakır, Erzincan, Gaziantep, Mersin, Osmaniye, Şanlıurfa. Recorded for the first time from Tunceli province.

\section{P. tricolor Weise, 1888}

Material examined: Elazığ: Kovancılar, Yukarı Kazan-

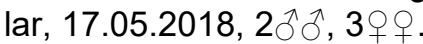

Distribution in Turkey: Aksaray, Ankara, Antalya, Artvin, Bayburt, Diyarbakır, Erzincan, Erzurum, Eskişehir, Hatay, Isparta, Konya, Kayseri, Kırşehir, Nevşehir, Niğde, Osmaniye, Samsun. Recorded for the first time from Elazığ province.

Remarks: Afyon, Çankırı and Kilis are also recently added to the known distribution area of this species (Özdikmen et al. 2020a).

\section{Genus Hypocassida Weise, 1893}

\section{H. subferruginea (Schrank, 1776)}

Material examined: Elazığ: Kovancılar, 17.05.2018, 1 .

Distribution in Turkey: Adana, Ağrı, Aksaray, Amasya, Ankara, Antalya, Aydın, Balıkesir, Bilecik, Bitlis, Bursa, Bolu, Burdur, Çanakkale, Çankırı, Çorum, Denizli, Düzce, Edirne, Erzincan, Erzurum, Eskişehir, Hatay, Isparta, İstanbul, İzmir, Kahramanmaraş, Karaman, Kastamonu, Kayseri, Kocaeli, Konya, Karabük, Kütahya, Manisa, Mersin, Muş, Niğde, Osmaniye, Rize, Sakarya, Samsun, Siirt, Sinop, Sivas, Şanlıurfa, Yozgat, Zonguldak. Recorded for the first time from Elazığ province.

\section{CONCLUSIONS}

The present study provides important contribution for the leaf beetle fauna of East Anatolia Region. Except the five species listed (Clytra novempunctata, Cryptocephalus duplicatus, Chrysolina orientalis, Radymna quadrimaculata, Altica oleracea) all the rest are new records for the collected provinces. Besides, the whole collected species are first records for Tunceli province. Smaragdina scutellaris and Galeruca jucunda are recorded for the first time outside of Ankara province. Radymna quadrimaculata is reported second time after its first record from Turkey and the presence of Galeruca spectabilis spectabilis in Turkey is confirmed with exact locality data (see remarks). These results show that extensive faunistic studies are needed in the eastern parts of Anatolia; more field studies will result in more interesting findings.

\section{ACKNOWLEDGEMENTS}

We are grateful to Dr. Ron Beenen (Naturalis Biodiversity Center, Leiden, the Netherlands) for his kind support and confirmation of some species.

\section{REFERENCES}

Aslan, E.G., Başar, M. (2016). Flea beetles collected from olive trees of Antalya province including the first record of the monotypic genus Lythraria Bedel, 1897 (Coleoptera: Chrysomelidae) for Turkey. Turkish Journal of Entomology. 40(3): 243-248.

Bal, N., Özdikmen, H., Kıyak, S. (2018a). Thirty new leaf beetles for the fauna of Çankırı province in Turkey (Chrysomelidae). Munis Entomology \& Zoology. 13(2): 507-518.

Bal, N., Özdikmen, H., Coral Şahin, D. (2018b). Twenty-six new flea beetles for the fauna of Çankırı province in Turkey (Chrysomelidae: Galerucinae: Alticini). Munis Entomology \& Zoology. 13(2): 527-537.

Beenen, R. (2010). Chrysomelidae: Galerucinae. In: Catalogue of Palaearctic Coleoptera, Vol. 6. Chrysomeloidea. Löbl, I., Smetana, A. (eds.), Apollo Books, Stenstrup, 443491.

Beenen, R. (2014). Key to the species of Radymna Reitter, 1913 with taxonomic and faunistic comments and description of two new species (Coleoptera, Chrysomelidae, Galerucinae). Entomologische Blätter und Coleoptera. 110: 87-100.

Beenen, R. (2019). Faunistic, taxonomic and nomenclatural notes on Palaearctic Galerucinae (Coleoptera, Chrysomelidae) with description of six new species and a new genus. Entomologische Blätter und Coleoptera. 115: 001-020.

Bezděk, J. (2018). Taxonomical changes, comments and new country records of West Palaearctic Chrysomelidae (Coleoptera) with special regards to Mediterranean species. Caucasian Entomological Bulletin. 14(Suppl.): 17-27.

Cizek, P., Doguet, S. (2008). Klic k urcovani drepciku (Coleoptera: Chrysomelidae: Alticinae) Ceska a Slovenska. Mestske muzeum, Nove Mesto nad Metuji, Slovenska.

Ekiz, A. N., Şen, İ., Aslan, E. G., Gök, A. (2013). Checklist of leaf beetles (Coleoptera: Chrysomelidae) of Turkey, excluding Bruchinae. Journal of Natural History. 47: 22132287.

Gök, A., Turantepe, E. (2019). Additions to the fauna of Chrysomelidae (Coleoptera) from Hatila Valley National Park (Artvin, Turkey), with notes on host plant preferences and zoogeographic evaluations. Caucasian Entomological Bulletin. 15(1): 135-146.

Gök, A., Bostan, K. (2020). The first faunistic data on the leaf beetles (Coleoptera: Chrysomelidae) of 26 Ağustos Nature Park, Afyonkarahisar, Turkey. Journal of the Entomological Research Society. 22(1): 83-99.

Hsiao, T.H. (1994). Molecular techniques for studying systematics and phylogeny of Chrysomelidae. Novel aspects of 
the Biology of the Chrysomelidae, 511-525. Series Entomologica, vol.50. Kluwer Academic Publishers, Dordrecht, The Netherlands.

Jolivet, P. (2015). Together with 30 years of Symposia on Chrysomelidae! Memories and personal reflections on what we know more about leaf beetles. In: Jolivet, P., Santiago-Blay, J., Schmitt, M. (Eds) Research on Chrysomelidae 5. ZooKeys. 547: 35-61.

Konstantinov, A. S., Korotyaev, B. A., Volkovitsh, M.G. (2009). Insect biodiversity in the Palearctic Region. In: Insect Biodiversity: Science and Society. Foottit, R.G., Adler, P.H. (eds.), Wiley Blackwell, Oxford, UK, 107-162.

Özdikmen, H., Mercan, N., Cihan, N., Kaya, G., Topcu, N.N., Kavak, M. (2014). The importance of superfamily Chrysomeloidea for Turkish biodiversity (Coleoptera). Munis Entomology \& Zoology. 9: 17-45.
Özdikmen, H., Bal, N., Kıyak, S. (2016). The genus Labidostomis Germar of Turkey with a new species and a new record (Coleoptera: Chrysomelidae: Clytrinae). Munis Entomology \& Zoology. 11(2): 515-538.

Özdikmen, H., Bal, N., Coral Şahin, D. (2020a). A contribution to the knowledge of leaf-beetles (Coleoptera: Chrysomelidae) in Turkey using data of specimens in Nazife Tuatay Plant Protection Museum (Turkey, Ankara). Munis Entomology \& Zoology. 15(1): 269-297.

Özdikmen, H., Coral Şahin, D., Bal, N. (2020b). A confirmation on the presence of four little known leaf-beetle speciesgroup taxa in Turkey with exact locality data (Coleoptera: Chrysomelidae). Munis Entomology \& Zoology. 15(1): 226228.

Warchalowski, A. (2010). The Palearctic Chrysomelidae: Identification Keys, Vol: 2. Natura Optima Dux Foundation, Warszawa. 